\title{
Membrane Processes during the Regeneration of Galvanic Solution
}

\author{
Serdiuk V. O. ${ }^{1}$, Sklavbinskyi V. I. ${ }^{1}$, Bolshanina S. B..$^{1 *}$, Ivchenko V. D. ${ }^{2}$, Qasim M. N. ${ }^{3}$, Zaytseva K. O. ${ }^{1}$ \\ ${ }^{1}$ Sumy State University, 2 Rymskogo-Korsakova St., Sumy 40007, Ukraine; \\ ${ }^{2}$ Sumy National Agrarian University, 160 H. Kondratieva St., Sumy 40021, Ukraine; \\ ${ }^{3}$ Institute of Technology, Middle Technical University, Baghdad, Iraq
}

Article info:

Paper received:

The final version of the paper received:

Paper accepted online:
June 21, 2018

October 2, 2018

October 5, 2018 *Corresponding Author's Address:
svet.bolshanina@gmail.com

\begin{abstract}
The process of $\mathrm{Cd}^{2+}$ and $\mathrm{Zn}^{2+}$ cations transfer through the cation exchange membrane RALEX®CM-PES 11-66 in double-chamber electrolyzer was investigated. Anodic chamber electrolyte (analyte) contained model solutions which imitates galvanic baths composition for passivation processes. The analyte contained $50 \mathrm{~g} / \mathrm{l}$ sodium dichromate and $10 \mathrm{~g} / 1$ sulfuric acid as main substances and impurities of $\mathrm{Cd}^{2+}$ and $\mathrm{Zn}^{2+}$ cations in amount of $2.5 \mathrm{~g} / \mathrm{l}$ of each. The electrolyte of cathode chamber is catholyte, contained $1 \%$ solution of sulfuric acid. The titanium grade BT-0 and lead grade C- 0 were used as cathode and anode respectively. Cathode processes connected with processes of ion migration through the membrane and metal release on cathode were studied. The creation of volt-ampere curves in galvanodynamic mode was supplied by impulse potentiometer, tool for combined measurements and silver chloride reference electrode. An increase of cathode overvoltage in the presence of cadmium ions and decrease of cathode potential with the increase of temperature were proved. The $\mathrm{pH}$ range for intensive reduction of metals was determined during investigations. Scanning electron microscopy with X-ray analysis was used for estimation of cathode deposits elemental composition. It was established that metal atoms of cadmium and zinc were presented in cathode deposits. Transference numbers of ions through cationic membrane were calculated for cadmium and mixture of cations proved the effectiveness of chromium and zinc ions extraction from chromium containing solutions. This process provides regeneration of galvanic solutions and maintains stable composition of passivation bath.
\end{abstract}

Keywords: electrolysis, galvanic solution, ion-exchange membrane, chromium-containing solution, cadmium cations, zinc cations.

\section{Introduction}

High aggressivity of hexavalent chromium-based solutions in galvanic production sewage waters causes significant environmental hazard. The $\mathrm{Cr}^{6+}$ compounds have toxic properties, take mutagenic and carcinogenic impact on living organisms $[1,2]$. The sources of such pollution are not only flushing waters, but also exhausted concentrated solutions of process baths [3]. The examples can be brightening and passivating bath solutions containing up to $100-200 \mathrm{~g} / \mathrm{l}$ of hexavalent chromium compounds. Active employment of such baths results in hexavalent chromium reduction, while solutions accumulate heavymetal ions. At the same time, the ratio of the essential components in these baths changes, that entails the need for adjustment by adding new portions of reagents. That leads to instability in bath operation and declining quality of coating [4]. In order to eliminate those defects, the contents of the baths must be replaced, while exhausted concentrated solutions are liable to be discharged into sediment tanks. The volley character of emptying doesn't allow treating facilities to neutralize toxic wastes completely that causes the risk of environmental pollution. Besides, when discharging hexavalent chromium compounds as a waste, the enterprise irretrievably loses the valuable component necessary for technological operations in the electroplating shop. The high level of solution contamination resulted from electroplating production, the presence of numerous organic compounds make it difficult to use reverse osmosis. The development and implementation of membrane-type electrochemical devices with the simultaneous return of the valuable components into production (in the form of commercial products and secondary raw materials) has been the only radical solution to the emerging problem so far. In this case, electrolysis with ion-exchange membranes is the most perspective treatment for such runoff $[5,6]$.

The electromembrane processes can be found in the submersible electrochemical modules. The feature of the processes taking place in these devices consists in the fact 
that the separation of the components occurs with the help of anionic or cationic membranes within the electrolytic module [7, 8]. Regeneration is carried out in batchtype electrolysers (electrolytic cells) with the premium brand membranes (MK-40, MA-40) [9]. Process solutions of rinsing baths or sulfuric acid solutions [3] are used as catholyte and anolyte depending on the type of electrolyser and the purpose of the process. Electrolysis is carried out using anodes and cathodes manufactured from different materials (e. g. platinized titanium, lead, steel) $[10,11]$.

In order to research the impact of individual technological parameters on membranous electrolyser operation, the given research explores the voltampere characteristics of the cathode and anode process, as well as the influence of temperature, electrolyte composition and medium acidity on the migration and electrochemical reduction of metal ions. Modeling of electrolyte composition proceeded from the features of the processes in real galvanic passivating baths [11]. These processes require the solutions with hexavalent chromium compounds. In such solutions as a result of operation hexavalent chromium gets reduced to $\mathrm{Cr}^{3+}$ from chromate $\left(\mathrm{CrO}_{4}{ }^{2-}\right)$ and dichromate $\left(\mathrm{Cr}_{2} \mathrm{O}_{7}{ }^{2-}\right)$ ions, while work zinc or cadmium coating dissolves. Consequently, ions of trivalent chromium and dissolving metal get accumulated in the solutions in accordance with the reaction equations (1) and (2):

$$
\begin{aligned}
& 3 \mathrm{Zn}+2 \mathrm{CrO}_{4}^{2-}+16 \mathrm{H}^{+} \rightarrow 3 \mathrm{Zn}^{2+}+2 \mathrm{Cr}^{3+}+8 \mathrm{H}_{2} \mathrm{O} \\
& 3 \mathrm{Cd}+\mathrm{Cr}_{2} \mathrm{O}_{7}^{2-}+14 \mathrm{H}^{+} \rightarrow 3 \mathrm{Cd}^{2+}+2 \mathrm{Cr}^{3+}+7 \mathrm{H}_{2} \mathrm{O}
\end{aligned}
$$

The accumulated ions of heavy metals, trivalent chromium with simultaneous deacidification make these solutions unserviceable. Considering the composition of passivating baths, as well as availability of the mentioned zinc $[12,13]$ and cadmium ions and trivalent chromium there, bath compositions were modeled under laboratory conditions by adding the defined amounts of salts of the specified metals to electrolyte which was subjected to electromembrane process $[3,14]$.

Due to the abovementioned, the objective of the work is to study the electrochemical regularities of membrane electrolysis of chromium-containing solutions which will allow to multiply the lifetime of galvanic baths and prevent the entry of toxic $\mathrm{Cr}^{6+}$ ions into the environment.

\section{Research Methodology}

In order to study the effect of different parameters on chromic solutions regeneration, the two-chamber electrolyser MECk (electrochemical cationic module) was produced inclusive of anode and cathode chambers separated by a cation-exchange membrane (Figure 1).

The external anode was dipped into the anode chamber that simulated a passivating bath. The cation-exchange membrane RALEX®CM-PES 11-66 was installed so that it formed one of the cathode chamber walls from the anode side. Filter cloth was tightly attached to the membrane from the anode side. The presence of filter cloth prevented from rapid membrane blinding [7].

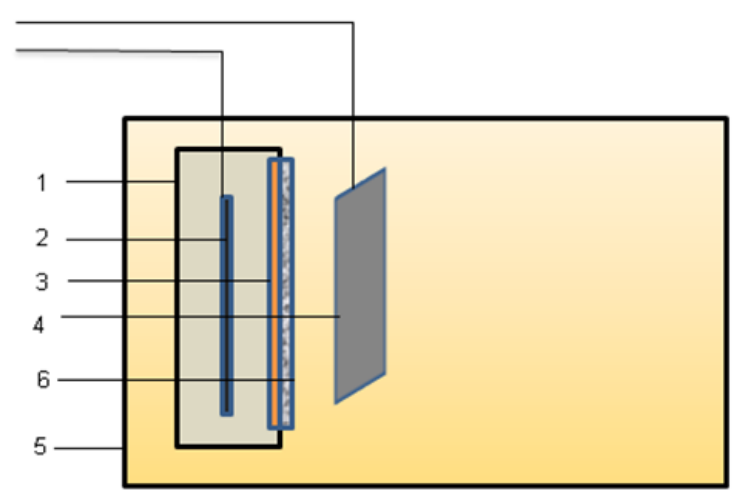

Figure 1 - The diagram of membrane external-anode electrolyser: 1 - cathode chamber body; 2 - internal electrode-cathode; 3 - ion-exchange membrane; 4 - external electrode-anode; 5 - chromic solution chamber; 6 - filter cloth

The anode material is lead ( $\mathrm{C} 2$ grade), the cathode material is titanium. Cathode and anode areas are $S_{K}=0.3$ $\mathrm{dm}^{2}$ and $S_{A}=0.72 \mathrm{dm}^{2}$ respectively. The $10 \mathrm{dm}^{3}$ anode chamber was filled with chromic solution of the following concentration: $\mathrm{Na}_{2} \mathrm{Cr}_{2} \mathrm{O}_{7}-50 \mathrm{~g} / \mathrm{l}, \mathrm{H}_{2} \mathrm{SO}_{4}-10 \mathrm{~g} / \mathrm{l}$. In order to simulate the bath operating conditions, cationcontaining compounds of the respective metals $\mathrm{Zn}^{2+}, \mathrm{Cd}^{2+}$ and $\mathrm{Cr}^{3+}$. were added to anodic solution. The content of the added ions in anodic solution (anolyte) complied with the concentration of $2.5 \mathrm{~g} / 1$ for each ion. The $1 \mathrm{dm}^{3}$ cathode chamber was filled with cathode liquor (catholyte) $-1 \%$ sulfuric acid solution. Electrolysis was carried out at current density of $0.3-3.0 \mathrm{~A} / \mathrm{dm}^{2}$ and $3-9 \mathrm{~V}$ voltage. Throughout the process, the catholyte's $\mathrm{pH}$ was being monitored. Cathode deposit was examined by scanning electron microscopy.

\section{Results}

As a primary method for studying electrical reduction of metal ions in chromic solution, we used the voltammetry method with linear potential sweep. Voltammograms were recorded in a galvanic-dynamic mode by means of the PI-50-1.1 pulse potentiostat and the Victor VC88C multimeter. To measure electrode potential drop, a silverchloride reference electrode was employed [13]. The measurement results showed that with current strength growth, the anode potential changed insignificantly (no more than $0.1-0.2 \mathrm{~V}$ ). The anode process is related to oxygen release and partial oxidation of trivalent chromium ions in $\mathrm{Cr}_{2} \mathrm{O}_{7}^{2-}$ [1].

Voltammograms of zinc and cadmium reduction on the cathode in the cathode chamber are presented in Figure 2.

Voltammograms of zinc and cadmium reduction on the cathode in the cathode chamber are presented in Figure 2. As follows from the graphs of electrode potential shift dependencies on current density, the presence of metal cation impurity reduces the overvoltage on the cathode (curves 2 and 3). However, it should be noted that the contribution of each of metal ions to the general decline in overvoltage is not the same. 


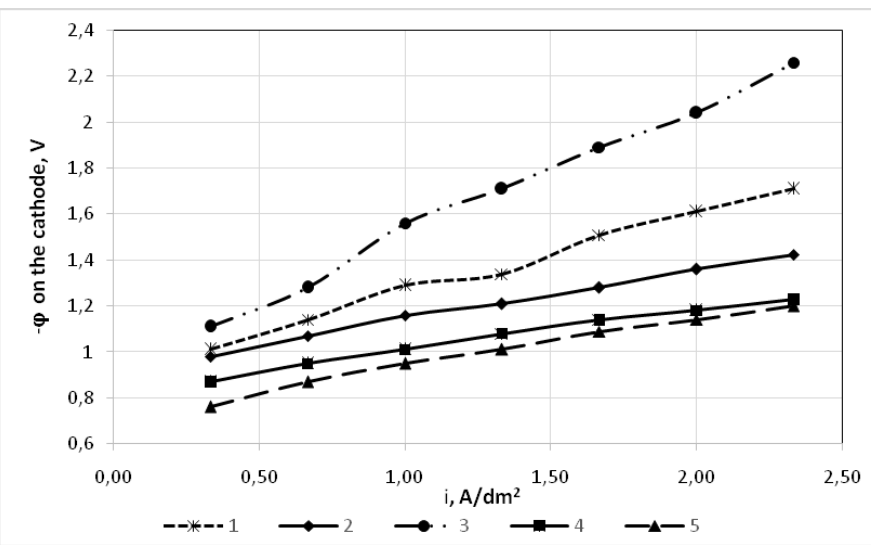

Figure 2 - Voltammogramsof cathodic electroreduction of metalsattheir migration through a cation-exchange membrane: $1,2,3$ - at electrolyte temperature of $14{ }^{\circ} \mathrm{C} ; 4,5,1-$ at $30{ }^{\circ} \mathrm{C}-$ an anolyte does not contain metal ions able to be deposited on the cathode; 2 - anolyte additionally contains $\mathrm{Zn}^{2+}$ ions ( $2.5 \mathrm{~g} / \mathrm{l}) ; 3$ - anolyte additionally contains $\mathrm{Zn}^{2+}$ ions ( $\left.2.5 \mathrm{~g} / \mathrm{l}\right)$ and $\mathrm{Cd}^{2+}(2.5 \mathrm{~g} / \mathrm{l}) ; 4$ - anolyte does not contain metal ions able to be deposited on the cathode; 5 - anolyte additionally contains $\mathrm{Zn}^{2+}$ ions $(2.5 \mathrm{~g} / \mathrm{l})$

Figure 3 presents voltammograms for electrolytes separately containing zinc and cadmium cations 1 and 2 respectively. As can be seen, the presence of cadmium ions significantly extends the cathode potential which seems to be connected with the increased conductivity of electrolyte.

Besides, the cathodic process is affected by the temperature (Figure 2). As the temperature rises, the electrolytic conductivity increases. This is connected with the reduced viscosity of solution (thinning) and increased mobility of ions. In addition, the increased temperature stimulates the increased number of active ions, contributes to the decrement of the effective radius of ions as a result of their shells dehydration.

The increase in electroconductivity reduces cathodic polarization (Figure 2, curves 4, 5). Electrode depolarization provides more active product deposition.

While studying the chemism of the ongoing electrode reactions, we can assume the resulting products. Thus, the following reactions can occur on the cathode and in cathode liquor (catholyte) during the electricity flow:

$$
\begin{gathered}
\mathrm{Zn}^{2+}+2 \mathrm{e}=\mathrm{Zn} \\
\mathrm{Cd}^{2+}+2 \mathrm{e}=\mathrm{Cd} \\
2 \mathrm{H}_{3} \mathrm{O}^{+}+2 \mathrm{e}=\mathrm{H}_{2}+2 \mathrm{H}_{2} \mathrm{O} \\
2 \mathrm{H}_{2} \mathrm{O}+2 \mathrm{e}=\mathrm{H}_{2}+2 \mathrm{OH}^{-}
\end{gathered}
$$

Trivalent chromium ions which are generated in the process of chrome plating in anodic solution in practice are not expected to pass to catholyte or be deposited on the cathode. They oxidize on the anode forming $\mathrm{Cr}_{2} \mathrm{O}_{7}{ }^{2-}$ [9]. However, as our research has shown, insignificant amounts of chromium compounds can still migrate to the cathode, but their presence is not more than $1 \%$ of the total amount of precipitate on the cathode (Figures 4, 5).

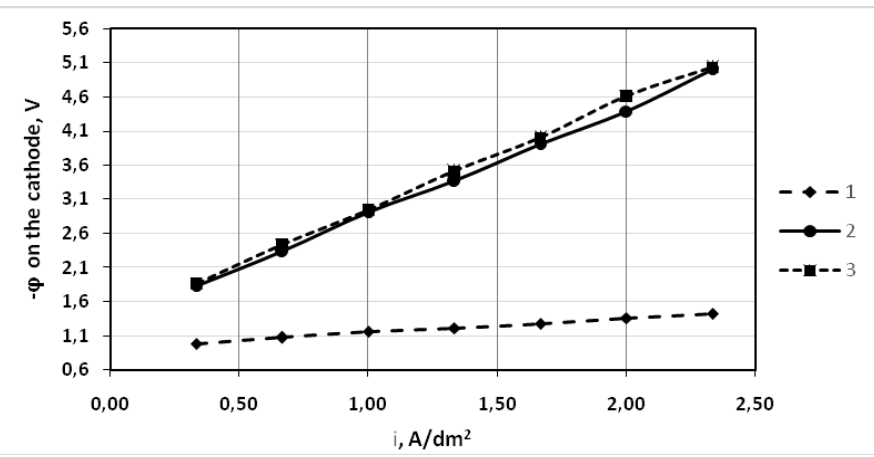

Figure 3 - Voltammograms of cathodic electroreduction of metal sat their migration through a cation-exchange membrane at electrolyte temperature of $14^{\circ} \mathrm{C}: 1-$ anolyte contains $\mathrm{Zn}^{2+}$

ions $(2.5 \mathrm{~g} / \mathrm{l}) ; 2$ - anolyte contains $\mathrm{Cd}^{2+}$ ions $(2.5 \mathrm{~g} / \mathrm{l})$;

3 - anolyte contains $\mathrm{Cd}^{2+}$ ions $(2.5 \mathrm{~g} / \mathrm{l}), \mathrm{Zn}^{2+}$ ions $(2.5 \mathrm{~g} / \mathrm{l})$ and $\mathrm{Cr}^{3+}$ ions $(2.5 \mathrm{~g} / \mathrm{l})$

As can be seen from the above-mentioned reactions, 5 and 6 cause the change in cathodic $\mathrm{pH}$ medium. Change in catholyte's acidity, its shift towards the alkaline side, leads to the drop of electrical conductivity of solution and formation of flaked insoluble metal hydroxides that result in module efficiency decrement.

$\mathrm{X}$-ray microanalysis conducted using the scanning electron microscope REM-106-i (manufactured by "SELMI", Ukraine) allowed determination of chemical elements in the samples of the studied cathodic deposits on the basis of energy values of the characteristic X-ray peaks of each chemical element $[15,16]$. To determine the elementary composition the samples were placed on a double-sided carbon adhesive tape. The prepared samples were placed in the electron microscope and examined at accelerating $20 \mathrm{kV}$ voltage in the secondary-electron mode within the range of electro-optical magnification from 600 to 6000 times (Figures 4, 5).

The accomplished analysis of cathode deposits formed at module operation with electron microscopy employment demonstrated that there were metal atoms in deposits which initially had not been available within catholyte. The spectrograms display the metals that were added to dichromate anodic solution - namely, cadmium and zinc. Their percentage in the deposit reaches 95-98\%. It should be noted that in case of their joint presence, cadmium content as much as 2 times exceeds zinc content. As to chromium, its presence in the deposit makes only a fraction of a percent and is considered to be negligible [11] (Table 1).

For the purpose of setting optimal $\mathrm{pH}$ values in catholyte, the change in the solution acidity in the process of electrolysis was under investigation. Simultaneously, the research of cathodic deposition products in the form of deposited metal was carried out at current strength of 0.7 A over the period from 1 up to 12 hours. The corresponding results are presented in Table 1. 


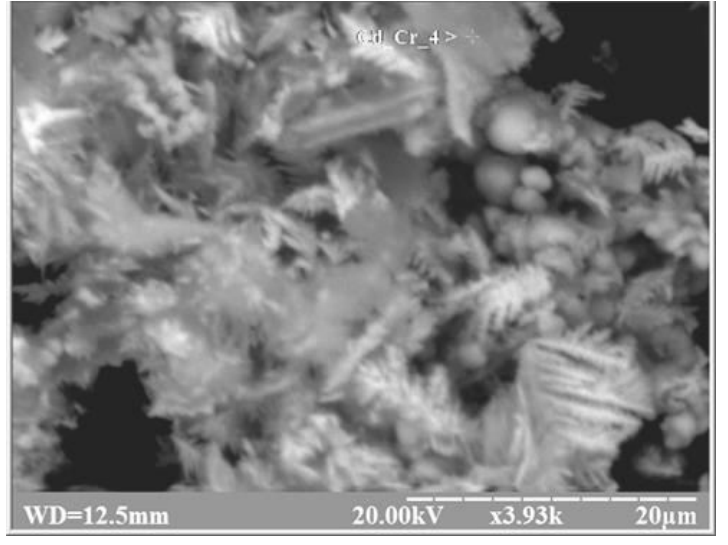

a

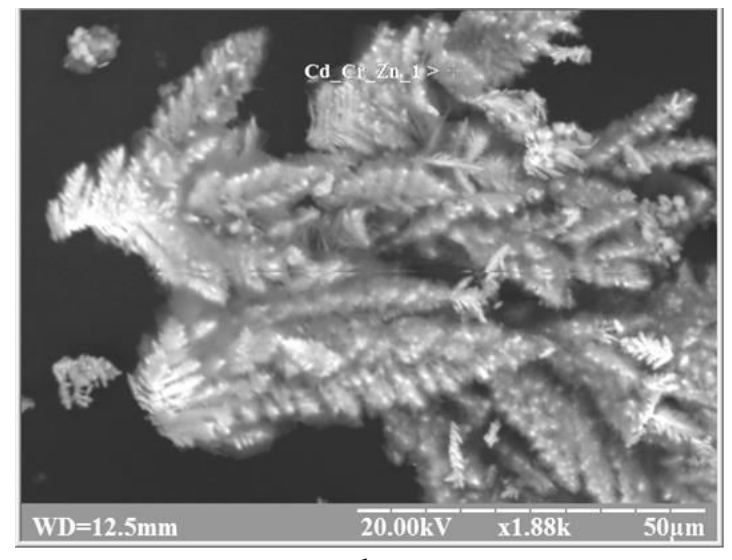

b

Figure 4 - REM photographs of cathodic deposit samples when the module is operated: a - anodic solution (anolyte) contains $\mathrm{Cd}^{2+}$ ions $(2.5 \mathrm{~g} / \mathrm{l}) ; \mathrm{b}$ - anolyte contains $\mathrm{Zn}^{2+}$ ions $(2.5 \mathrm{~g} / \mathrm{l})$ and $\mathrm{Cd}^{2+}(2.5 \mathrm{~g} / \mathrm{l})$

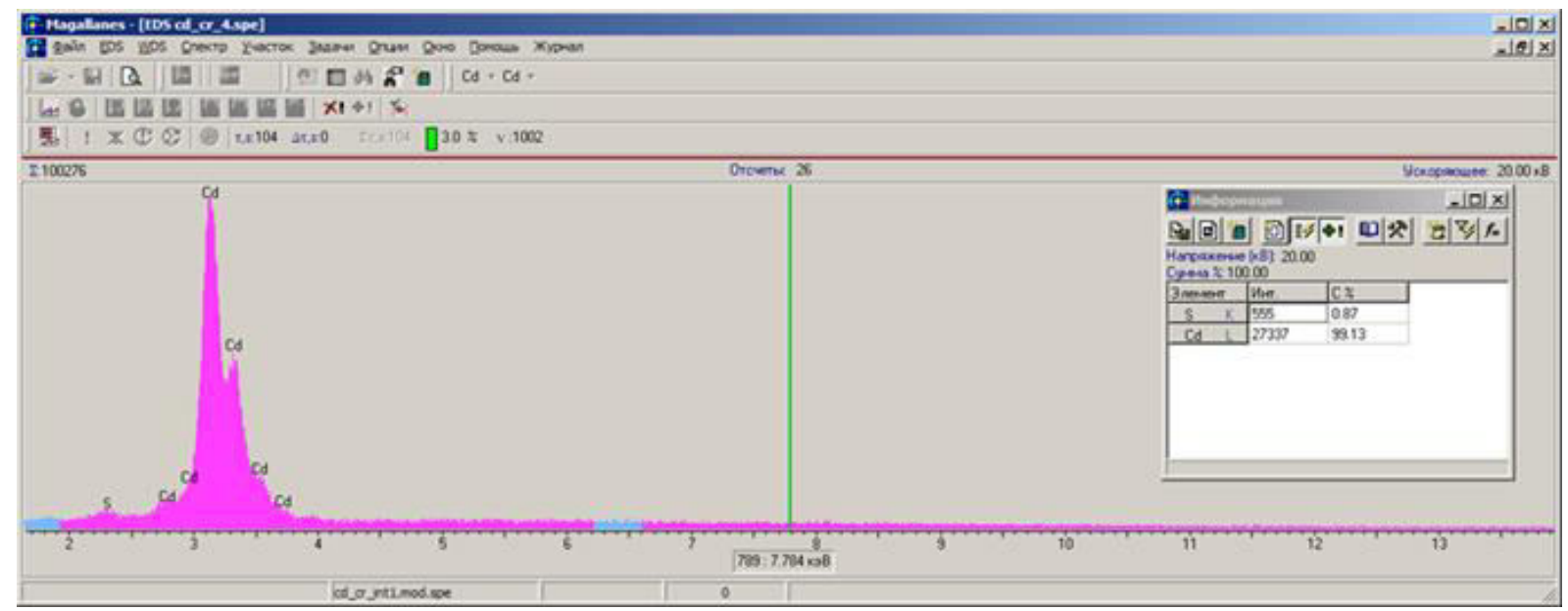

a

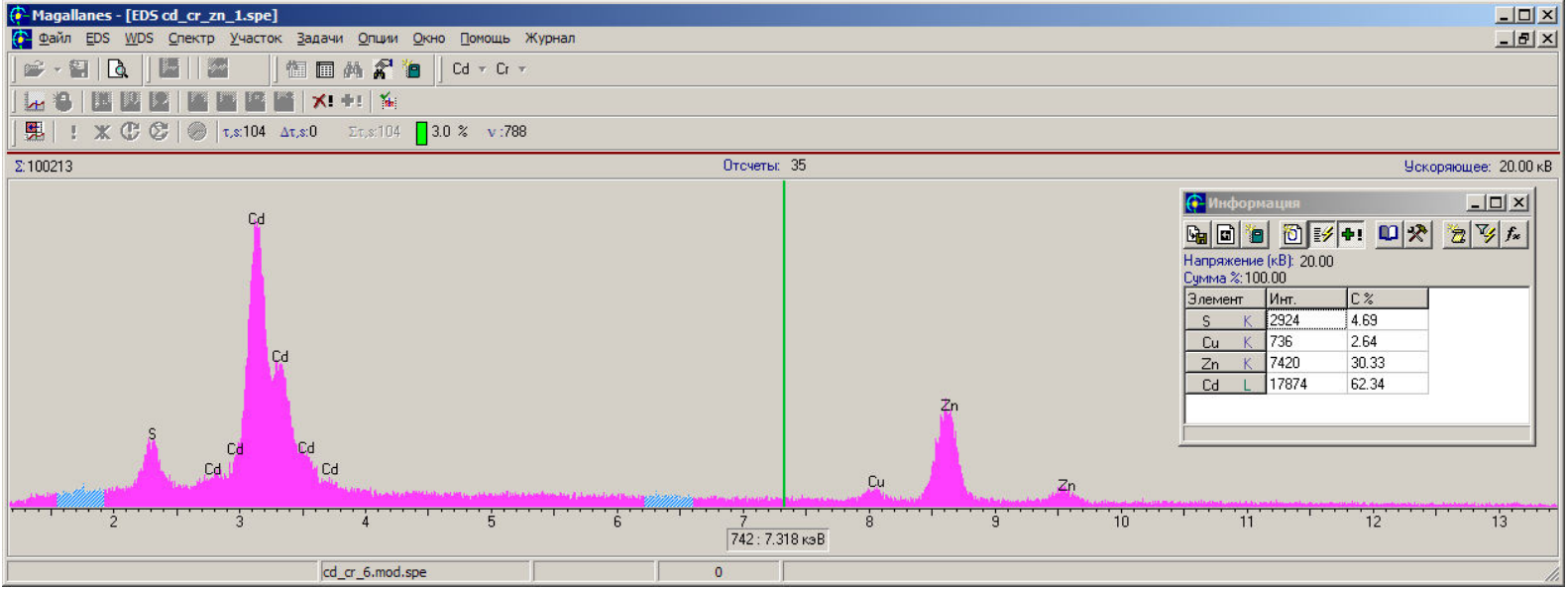

b

Figure 5 - Spectrograms of cathode deposit samples and the results of microanalysis: a - the anolyte contains $\mathrm{Cd}^{2+}$ ions $(2.5 \mathrm{~g} / \mathrm{l})$ (Figure $4 \mathrm{a})$; $\mathrm{b}$ - the anolyte contains $\mathrm{Zn}^{2+}$ ions $(2.5 \mathrm{~g} / \mathrm{l})$ and $\mathrm{Cd}^{2+}(2.5 \mathrm{~g} / \mathrm{l})$ (Figure $\left.4 \mathrm{~b}\right)$ 
Table 1 - Changes in the catholyte acidity and the mass of metals deposited on the cathode at electrochemical module operation

\begin{tabular}{|c|c|c|c|c|}
\hline \multirow[b]{2}{*}{$\begin{array}{c}\text { Module } \\
\text { operating time }\end{array}$} & \multicolumn{2}{|c|}{ Catholyte $\mathrm{pH}$ value } & \multicolumn{2}{|c|}{ Masses of metals on the cathode, (operational) } \\
\hline & $\begin{array}{l}\text { Anolyte with } \\
\text { the only impurity of } \\
\qquad \mathrm{Cd}^{2+}\end{array}$ & $\begin{array}{l}\text { Anolyte with } \\
\text { the impurities of } \\
\mathrm{Zn}^{2+}, \mathrm{Cd}^{2+} \mathrm{Cr}^{3+}\end{array}$ & $\begin{array}{l}\text { Anolyte with } \\
\text { the only impurity of } \\
\mathrm{Cd}^{2+}\end{array}$ & $\begin{array}{l}\text { Anolyte with } \\
\text { the impurities of } \\
\mathrm{Zn}^{2+}, \mathrm{Cd}^{2+} \mathrm{Cr}^{3+}\end{array}$ \\
\hline 1 & 1.00 & 1.00 & 0.000 & 0.00 \\
\hline 3 & 1.30 & 1.30 & 0.020 & 0.02 \\
\hline 6 & 1.41 & 1.50 & 0.080 & 0.15 \\
\hline 9 & 1.61 & 1.65 & 0.253 & 0.37 \\
\hline 12 & 2.07 & 1.86 & 0.333 & 0.47 \\
\hline
\end{tabular}

From the values presented in the table, it is possible to determine that the greatest amount of deposited metal is observed at $1.5-1.8 \mathrm{pH}$ values. This corresponds to the highest electrical conductivity of catholyte solution. At a $\mathrm{pH}$ less than 1.5 , hydrogen is actively reducts at the cathode which interferes with the metal recovery process, and at $\mathrm{pH}$ greater than 1.8-2, insoluble metal hydroxides begin to form in the catholyte which also inhibits with the process. Over 12 hours of module operation, the cathodic $\mathrm{pH}$ increases insignificantly. It should be noticed that over the next 3 hours (13th, 14th and 15th hour) $\mathrm{pH}$ rises dramatically up to 5-6. At the same time the release of metal on the cathode practically ceases and the presence of insoluble hydroxides in the catholyte increases [14]. In this case metal deposition on the cathode is practically terminated, whereas the presence of insoluble hydroxides in cathode liquor increases. Matching of yield of metal resulting from electrolysis for every 3 hours with the change in catholyte $\mathrm{pH}$ is presented on the diagram (Figure 6).

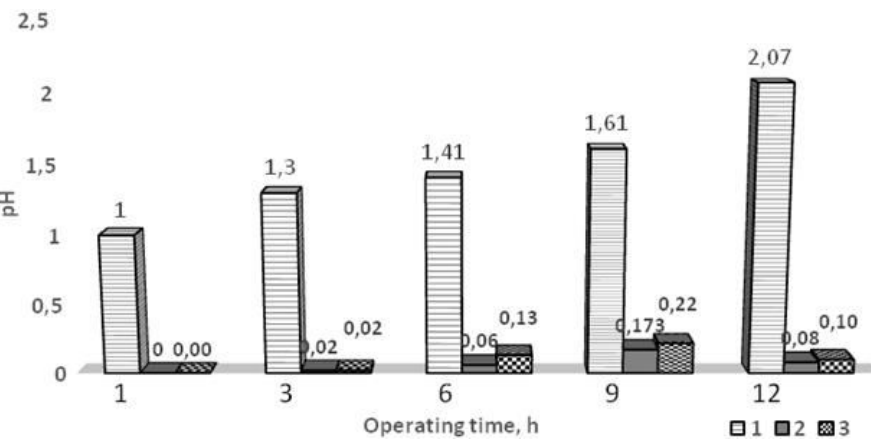

Figure 6 - Change in catholyte $\mathrm{pH}$ and mass of metals deposited on the cathode over the periods of module operation: $1,3,6,9$, and 12 hours at the electrolyte temperature of $14{ }^{\circ} \mathrm{C}$ :

1 - catholyte $\mathrm{pH} ; 2$ - anolyte contains $\mathrm{Zn}^{2+}$ ions ( $\left.2.5 \mathrm{~g} / \mathrm{l}\right)$;

3 - anolyte contains ions of $\mathrm{Zn}^{2+}(2.5 \mathrm{~g} / \mathrm{l})$ and $\mathrm{Cd}^{2+}(2.5 \mathrm{~g} / \mathrm{l})$

The data presented in Table 1 and Figure 6 makes it possible to calculate the numbers of metal ion transfer from the regenerated solution (anolyte) to catholyte. The transfer numbers of metal ions from the anolyte to the catholyte through the cation-exchange membrane were calculated taking into account the change of the volumes of these solutions. In the electrolysis process the volume of the catholyte was slightly increasing and the anolyte volume was decreasing, which is due to the migration of water. The ion transfer numbers for both cadmium and a mixture of cations are $0.011-0.009$ respectively. In spite of this, about $13 \%$ of cadmium and $11 \%$ of cadmium and zinc ions were removed during 12 hours of the module operation when they were both in the anolyte.

\section{Conclusions}

The investigation of the electrolysis of chromiumcontaining solutions using a module with a cationexchange membrane showed that this process allows the solution to be regenerated by extracting metal ions that contaminates it. The study of the specific indicators and characteristics of this process showed the following.

Volt-ampere characteristics taken in galvanostatic mode indicate a significant overvoltage at the cathode in the presence of metal ions $\left(\mathrm{Cd}^{2+}\right)$, which is due to the membrane resistance.

Temperature affects the cathode potential. With the temperature increasing, the polarization of the cathode decreases, that contributes to a more efficient conduct of the process.

Using the method of electron microscopy with the functions of X-ray phase microanalysis it is established that cadmium and zinc metal atoms are present in the composition of cathode deposit that were in the anolyte as impurities.

The cathode metal reduction depends on the medium acidity. In the course of the research, the $\mathrm{pH}$ interval was assigned at which the process of electrolysis is the most intensive. It corresponds to the values of 1.5-1.8. With the further $\mathrm{pH}$ increasing the electrolyte conductivity decreases due to the formation of insoluble hydroxides in the catholyte. Besides, it should be noticed, that metal reduction is complicated by a parallel cathodic reaction hydrogen release, especially at a $\mathrm{pH}$ of less than 1.3 .

The efficiency indicators of cadmium and zinc ions extraction from chromium-containing solutions allows to maintain a stable composition of the baths and completely to eliminate the discharge of toxic substances and heavy metal compounds into the sewage. 


\title{
References
}

1. Qian, Y., Huang, L., Pan, Y., Quan, X., Lian, H., \& Yang, J. (2017). Dependency of migration and reduction of mixed $\mathrm{Cr}_{2} \mathrm{O}_{7}^{2-}$, $\mathrm{Cu}^{2+}$ and $\mathrm{Cd}^{2+}$ on electric field, ion exchange membrane and metal concentration in microbial fuel cells. Separation and Purification Technology, Vol. 192, No. 9, pp. 78-87, doi: 10.1016/j.seppur.2017.09.049.

2. Bolshanina, S. B. (2016). Chemical Industry in Ukraine, Vol. 1 (132), pp. 13 [in Russian].

3. Yao, Y., Wei, Q., Sun, M., Chen, Y., \& Ren, X. (2013). The Royal Society of Chemistry, Vol. 3, Art. no. 13131.

4. Bolshanina, S. B., Ablieyeva, I. Yu., Kyrychenko, O. M., Altunina L. L., Klimanov O. B., \& Serdiuk, V. O. (2016). Method of Electrolytic Regeneration of Chromium-Containing Solutions. Patent of Ukraine, No. 109623, MPC (2006.01) C02F 1/46.

5. Benvenuti, T., Krapf, R. S., Rodrigues, M. A. S., Bernardes, A. M., \& Zoppas-Ferreira, J. (2014). Recovery of nickel and water from nickel electroplating wastewater by electrodialysis. Separation and Purification Technology, Vol. 129, No. 29, pp. 106112, doi: 10.1016/j.seppur.2014.04.002.

6. Dimitris, P., Zagklis, E. C., Arvaniti, V. G., et al. (2013). Sustainability analysis and benchmarking of olive mill wastewater treatment methods. Journal of Chemical Technology and Biotechnology, Vol. 88, pp. 742-750.

7. Kruglikov, S. S., \& Kolotovkina, N. S. (2013). Electroplating and Surface Treatment, Vol. 21, No. 3, pp. 63 [in Russian].

8. Kruglikov, S. S., Kolotovkina, N. S., et al. (2008). Electroplating and Surface Treatment, Vol. 16, No. 1, pp. 34 [in Russian].

9. Nekrasova, N. E., Nevmyatullina, Kh. A., Kharin, P. A., \& Kruglikova, E. S. (2016). Application of a two-chamber immersion electrochemical module for increasing the stability of a lead anode in aggressive media. Electroplating and Surface Treatment, Vol. 24, No. 1, pp. 22.

10. Turek, M., Mitko, K., Chorazewska, M., \& Dydo, P. (2013). Use of the desalination brines in the saturation of membrane electrolysis feed. Desalination and Water Treatment, Vol. 51, pp. 2749-2754.

11. Davoudi, M., Gholami, M., Naseri, S., Mahvi, A. H., Farzadkia, M., Esrafili, A., \& Alidadi, H. (2014). Application of electrochemical reactor divided by cellulosic membrane for optimized simultaneous removal of phenols, chromium, and ammonia from tannery effluents. Toxicological and Environmental Chemistry, Vol. 96, Issue 9, pp. 1310-1332.

12. Carrillo-Abad, J., Garcia-Gabaldon, M., \& Perez-Herranz, V. (2017). pH effect on zinc recovery from the spent pickling baths of hot dip galvanizing industries. Separation and Purification Technology, Vol. 177, No. 28, pp. 21-28.

13. Abbasi-Garravand, E., \& Mulligan, C. N. (2014). Using micellar enhanced ultrafiltration and reduction techniques for removal of $\mathrm{Cr}(\mathrm{VI})$ and $\mathrm{Cr}(\mathrm{III})$ from water. Separation and Purification Technology, Vol. 132, No. 20, pp. 505-512.

14. Hu, Ch.-Y., Shih, K., \& Leckie, J. O. (2010). Formation of copper aluminate spinel and cuprous aluminate delafossite to thermally stabilize simulated copper-laden sludge, Journal of Hazardous Materials, Vol. 181, Issue 1, pp. 399-404.

15. Durgun, I., \& Ertan, R. (2014). Experimental investigation of FDM process for improvement of mechanical properties andproduction cost. Rapid Prototyping Journal, Vol. 20, Issue 3, pp. 228-235, doi: 10.1108/RPJ-10-2012-0091.

16. Wenner, S., Jones, L., \& Marioara, C. D., Holmestad, R. (2017). Atomic-resolution chemical mapping of ordered precipitates in $\mathrm{Al}$ alloys using energy-dispersive X-ray spectroscopy, Micron, Vol. 96, pp. 103-111, doi: 10.1016/j.micron.2017.02.007.

\section{Мембранні процеси при регенерації гальванічного розчину}

\author{
Сердюк В. О. ${ }^{1}$, Склабінський В. І. ${ }^{1}$, Большаніна С. Б. ${ }^{1}$, Івченко В. Д. ${ }^{2}$, Касім М. Н. ${ }^{3}$, Зайцева К. О. ${ }^{1}$
}

\footnotetext{
${ }^{1}$ Сумський державний університет, вул. Римского Корсакова, 2, м. Суми, 40007, Україна;

${ }^{2}$ Сумський національний аграрний університет, вул. Г. Кондратьєва, 160, м.Суми, 40021, Україна;

${ }^{3}$ Технологічний інститут, Технічний університет, м. Багдад, Ірак
}

\begin{abstract}
Анотація. Досліджено процес перенесення катіонів $\mathrm{Cd}^{2+} \mathrm{i} \mathrm{Zn}^{2+}$ через кат іонообмінну мембрану RALEX®CM-PES 11-66 у двокамерному електролізері. Електроліт анодної камери (аноліт) містив модельний розчин, що імітував склад гальванічних ванн для процесів пасивації, зокреема натрій дихромат (50 г/л) i

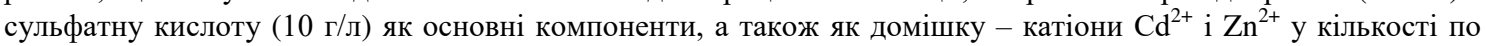
2,5 г/л кожного. Електроліт катодної камери (католіт) містив 1 \% розчин сульфатної кислоти. Як катод використовувався титан ВТ-0, як анод - свинець С-0. У результаті вивчені катодні процеси, що пов'язані із міграцією йонів крізь мембрану та виділенням металів на катоді. Використано метод побудови вольтамперних кривих у гальванодинамічному режимі за допомогою імпульсного потенціостату, приладів комбінованих вимірювань і хлор-срібного електроду порівняння. Доведено зростання перенапруги на катоді у присутності йонів кадмію та зниження потенціалу катода при підвищенні температури. У ході досліджень встановлений інтервал $\mathrm{pH}$, для якого процес катодного відновлення металів $\epsilon$ найінтенсивнішим. Використано метод скануючої електронної мікроскопії 3 функцією рентгенівського мікроаналізу для визначення елементарного складу катодних осадів. Встановлено, що до складу осадів на катоді входять атоми кадмію та цинку. Розраховані числа перенесення йонів крізь катіонообмінну мембрану для кадмію і для суміші катіонів, що підтверджує ефективність вилучення йонів кадмію та цинку із хромовмісних розчинів. Цей процес дозволяє регенерувати гальванічні розчини та підтримувати стабільний склад ванн пасивування.
\end{abstract}

Ключові слова: електроліз, гальванічний розчин, іонообмінна мембрана, хромовмісний розчин, катіони кадмію, катіони цинку. 